\title{
Selection Approach of Urban Trees for Inner-city Environments: Learning from Nature
}

\author{
Henrik Sjöman, Allan Gunnarsson, Stephan Pauleit, and Roland Bothmer
}

\begin{abstract}
High diversity of species and genera and site adaptation are two important factors in achieving a healthy and sustainable urban tree population. This paper presents and discusses a selection procedure for the identification of trees adapted to inner city environments. The procedure is based on dendroecological studies of trees in natural habitats, with similarities in climate and site conditions as inner city environments. By studying trees in such habitats, firsthand information can be gained on the growth and performance of a wide range of species and genotypes. Two field studies were conducted, one in central China and another in northeast Romania and the adjoining Republic of Moldavia with the aim to identify tree species and genotypes adapted to inner city environments in the northern parts of central Europe and the adjoining milder parts of northern Europe. In total, 27 tree species were identified as specialists for warm and periodically dry habitats. Of these tree species, only four are currently used frequently or used to some extent in northern Europe, meaning that 23 other tree species identified in the case studies can be potential supplements for diversification of the urban tree population.

Key Words. China; Dendroecology; Moldavia; Romania; Selection; Urban Environments; Urban Trees.
\end{abstract}

Urban trees have aesthetic, socio-cultural, environmental, and economic values that are beneficial for the sustainability and quality of life in urban areas (Nowak 2002; Tyrväinen et al. 2005). Greenspaces and particular areas with trees can also play an important role for adaptation of cities to climate change (Gill et al. 2007). However, trees need to be healthy, well-growing, and long-lived to provide these services (GómezMuñoz et al. 2010). The average lifespan of street trees and of other trees living in paved environments exposed to high stress is often rather short (Sæbø et al. 2005), and can be as low as only 10 years (Foster and Blaine 1977; Gilbertson and Bradshaw 1990; Nowak et al. 1990). Surviving trees are often in a poor condition. The main reason for this decline is the difference in environmental conditions provided in the urban landscape compared with that of the habitats within which most trees in the urban landscape originate (Sieghardt et al. 2005).

The modern city has changed dramatically due to the effects of the urban heat island (UHI), restricted rooting space, water-impervious surfaces and poor growth substrates. This makes trees planted along streets and in paved sites suffer particularly due to lack of water and oxygen, as well as unbalanced provision of nutrients (e.g., Craul 1999; Hoff 2001; Sieghardt et al. 2005; Nielsen et al. 2007). A recent study showed that even in a Nordic city with a cool climate, such as Copenhagen, Denmark, street trees suffer from lack of water even in summers that are actually considerably wetter than average in Copenhagen (Bühler et al. 2007).

Creating good growing conditions is therefore imperative for sustainable development of the urban stock of trees (Trowbridge and Bassuk 2004). Recent research has concentrated on the development of methods and techniques to improve habitat conditions in the city. In particular, the soil and rooting zone have been in focus (e.g., Grabosky and Bassuk 1996; Kristoffersen 1999; Pedersen et al. 2000; Trowbridge and Bassuk 2004; Roberts et al. 2006; Morgenroth and Visser 2011). However, improved methods for tree planting in paved urban sites will not provide similar growing conditions as in forests and parks. Therefore, the selection of a broad range of hardy species and genotypes for urban paved sites remains an important task, even more so if climate conditions become more adverse for urban tree life through climate change. For Central and Northern Europe, air temperatures are predicted to be higher, and periods of drought during summertime will increase (EEA 2008).

With climate change, the future urban tree stock also needs to withstand such challenges as an increase in pests and diseases. It has thus been suggested that the urban forest should be diversified. Some researchers have indicated that no species should represent more than $10 \%$, no genus more than $20 \%$, and no family more than $30 \%$ of the total population (Santamour 1990). However, surveys have shown that the reality is different and dictated by traditions rather than based on rules grounded in science. This narrow choice of species and genotypes is particularly apparent in Northern Europe. In a compilation by Sæbø et al. (2005, based on a survey by Pauleit et al. 2002), eight tree species were reported to be the most common species in street environments in Northern Europe: Acer platanoides L., A. pseudoplatanus L., Aesculus hippocastanum L., Betula pendula Roth., B. pubescens Ehrh., Populus trichocarpa Torr., Sorbus spp. [e.g., Sorbus $\times$ intermedia (Ehrh.) Pers.], and Tilia $\times$ europaea $\mathrm{L}$. However, the main natural habitats for these species, except Betula pendula and Sorbus $\times$ intermedia, are 
in nutrient-rich and moist sites where they develop into large and tenacious trees, while they show noticeably weaker development in inferior conditions (Ellenberg 1988; Påhlsson 1998). Thus there are currently two important directions in the selection of urban trees: 1) Increasing the knowledge and experience of site-adapted species useful for the varying growing conditions in urban environments; and 2) increasing the knowledge and experience of new and/or untested tree species with the potential to complement the existing urban tree population in the region.

Research on the selection and testing of alternative tree species, genotypes, and provenances is underway in several countries, but with different objectives. In forestry, the main focus in selection and breeding programmes continues to be on fast-growing and high-performing genotypes of mainly, already widely used forest tree species and on resistance to different pests and diseases (Perry 1998; Lu and Charrette 2008; Buránek et al. 2011). In the selection programmes for urban environments, the criteria do not differ greatly, apart from omitting commercial aspects such as timber production. Some examples of species selection programmes in Europe are presented by Sæbø et al. (2005). In this field, two main strategies are suggested. The first is to concentrate on the genetic aspect of already much-used species in order to identify the best varieties and genotypes in relation to city habitats. The second strategy involves broadening the range of urban tree species through a focused selection of species found in habitats showing similar conditions to city habitats. In this latter direction, Sæbø et al. (2005) describe a project in Greece where species are recommended after analyses of their natural requirements of soil conditions and climate. Furthermore, Ducatillion and Dubois (1997) based their selection on information from bibliographies, archives, and observations of living plants in southern France.

When using habitat studies in the search for potential species and genotypes, it is unlikely that the species-poor native dendroflora of the northern parts of Central Europe and the adjacent milder parts of Northern Europe (abbreviated to CNE-region; Ellenberg 1988) can provide a large range of species with extended tolerance of the environmental stresses characterising, for example, paved sites within urban areas of the region (Duhme and Pauleit 2000). Other regions with a comparable climate but with a richer dendroflora may have the potential to provide new tree species, genera, and genotypes for this purpose (Takhtajan 1986; Breckle 2002; Burga et al. 2005; Roloff et al. 2009; Sjöman and Richnau 2009). The key question is thus how to identify-with limited means and in a relatively short time-the right species and genotypes for further testing. The wealth of potentially suitable species from areas such as China is overwhelmingly large, which means that strategies for how and where to start searching, and how to make the right choice, need to be developed.

The objective of this paper is to present and discuss the first step in a selection procedure based on dendroecological studies in natural habitats in order to identify promising urban trees for inner-city environments in the CNE-region. This approach is illustrated with two case studies, one in central China and the other in northeast Romania and adjacent parts of the Republic of Moldavia, where habitat studies were carried out in natural habitats comparable to the growing conditions of inner-city environments in the CNE-region (Sjöman et al. 2010; Sjöman et al. 2012).

\section{DEVELOPMENT OF THE SELECTION APPROACH}

The grand old man in the sphere of modern arboriculture, Alex Shigo (1991), once said about the use and maintenance of city trees: "...we must understand the tree as it grows in its natural site first. To try to treat a city tree without understanding the tree as it grows in its natural site is like drawing a data curve with only an y axis; and no base line!"

In natural habitats, trees have been stress-tested and selected over evolutionary periods of time. Some species have developed an extensive plasticity and tolerance to a range of environmental conditions, while others are specialized to certain habitat types (Rabinowitz 1981; Oliver and Larson 1996; Gurevitch et al. 2002). Investigating the ecological background, and performance of species growing in habitats with drought during the growing season and winter temperatures similar to those of inner-city environments in a particular area, can assist in identifying alternative tree species and genotypes (Flint 1985; Ware 1994; Ducatillion and Dubois 1997; Broadmeadow et al. 2005; Sæbø et al. 2005; Roloff et al. 2009). The selection approach presented here comprises four steps (Figure 1). The first step is to identify floristically rich regions where the climate is similar to the CNE-region (Breckle 2002). In a second step, habitats where trees experience warm, dry summers with periodical drought are identified. Then third, dendroecological studies are conducted in the identified habitats (Roloff et al. 2009) in order to identify specialists for this type of habitat. Fourthly, seeds from identified species and genotypes are then collected in order to obtain appropriate genetic materials to be included in controlled selection programmes (Gurevitch et al. 2002; Mijnsbrugge et al. 2010). Already after Step 3 it is possible to identify the species for further evaluation (Figure 1).

The case studies were chiefly directed to follow Steps 1 to 3. Through this procedure, two levels of results were achieved. The first group of species identified are already in cultivation and available at tree nurseries. The second group of species have rarely or never been cultivated in the CNE-region (Figure 1).

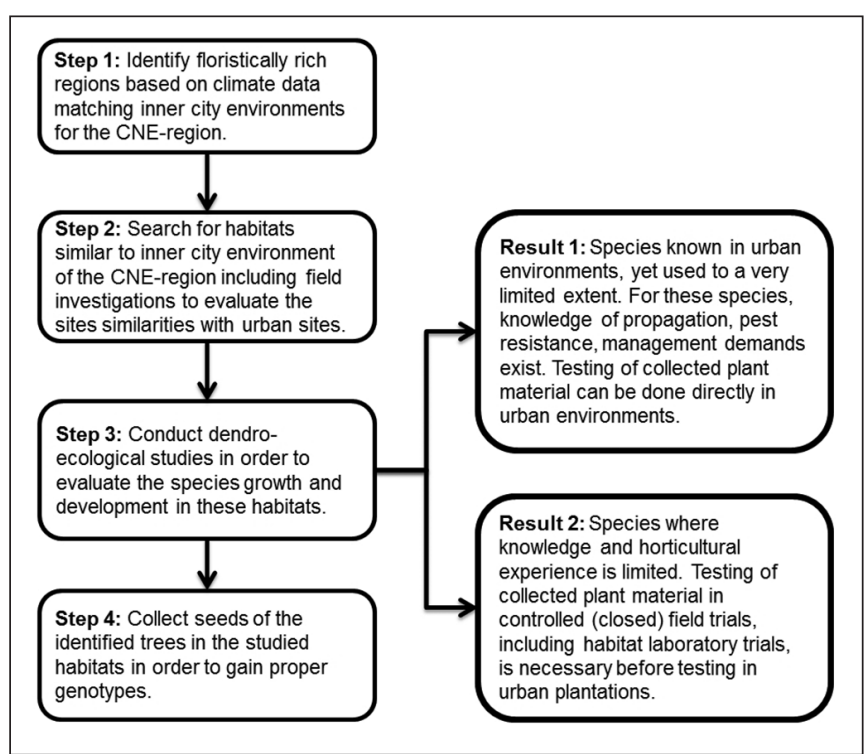

Figure 1. The first steps in a habitat-based selection of tree species suitable for urban areas in the CNE-region, including two result levels depending on earlier experiences of the species. 


\section{Step 1: Identification of Floristically Rich Regions}

There are numerous geographical regions in the world with a climate regime similar to the microclimate of streets, squares, and courtyards in the CNE-region (Takhtajan 1986; Ellenberg 1988; Breckle 2002; Burga et al. 2005). Information on such regions can be gained partly from botanical, ecological, and dendrological literature combined with local climate data, and partly from earlier experiences of species in cultivation from these regions. Figure 2 presents examples of geographical regions with a rich dendroflora and species used in the CNEregion with the potential to tolerate warm and periodically dry conditions. These species can hence serve as markers in the search for interesting and promising habitats where further suitable tree species and genotypes can be expected to grow (Kollmann and Fischer 2003). The steppe forests of northeast Romania and Moldavia and the species-rich mountains of central China are used as model areas. These two regions include species that have been in use in the CNE-region for a long time and have been observed to perform well in paved spaces. For example, Quercus frainetto Ten., native to northeast Romania, and Styphnolobium japonicum (L) Schott., native to the mountains of central China, have both been used and recommended for urban environments in the CNE-region (Bengtsson 1998).

In order to identify the potential of a region to host appropriate tree species for particular areas, such as inner-city environments, Sjöman and Richnau (2009) presented an approach based on climatological comparisons and calculation of the potential water net differences. For these calculations the regression presented by Thornthwaite (1948) was used, with monthly potential evapotranspiration based on the values of temperature, precipitation, number of sunshine hours per day, estimated water runoff, and cloudi- ness. These results indicate seasonal temperatures and show similarities and regards where, when, and how much water stress occurs during the growing season (Figure 3).

\section{Step 2: Search for Habitats Similar to Inner-city Environments}

Even if it is possible to identify a region's potential to host appropriate tree species for inner-city environments based on climate data, it is also important to find appropriate sites and microclimates because they can differ considerably within short distances, particularly in mountain regions (Barry 2008). For example, the climate and water availability for plants can differ significantly between a south-facing slope and a north-facing slope at the same altitude, influencing the vegetation structure and species compositions in the stands (Figure 3; Sjöman et al. 2010). The direct exposure to sunlight on steep south-facing slopes causes low air humidity and rapid drying of the soil, which is comparable to the situation at many urban paved sites (Sieghardt et al. 2005).

In order to gain such local site-related information, literature and field measurements are necessary, including soil samples for evaluation of soil texture, humus content, and $\mathrm{pH}$ value (FAO 2006). This soil-related data gives valuable guidance in matching urban sites in terms of soil water-holding capacity and other important variables (Craul 1999; Sieghardt et al. 2005). In mountainous regions, slope steepness is an important factor since water runoff data are crucial in calculating the net water differences in stands (Thornthwaite 1948).

\section{Step 3: Evaluation of Tree Growth and Performance}

After identification of appropriate regions and habitats, where plants are exposed to cold winter temperatures in combination

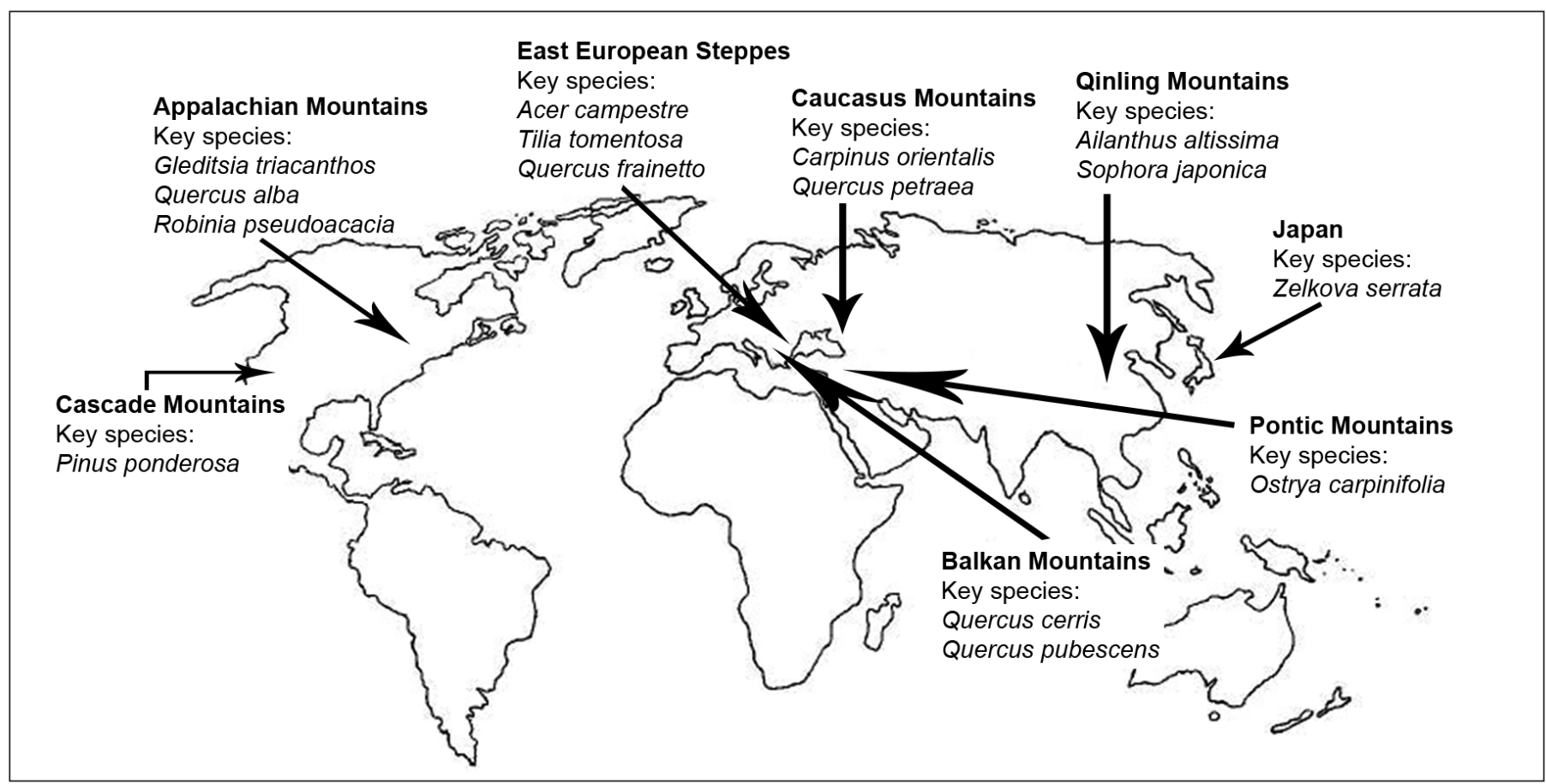

Figure 2. Areas around the world with examples of interesting species and genotypes, when searching for regions with woody species for urban plantings. 


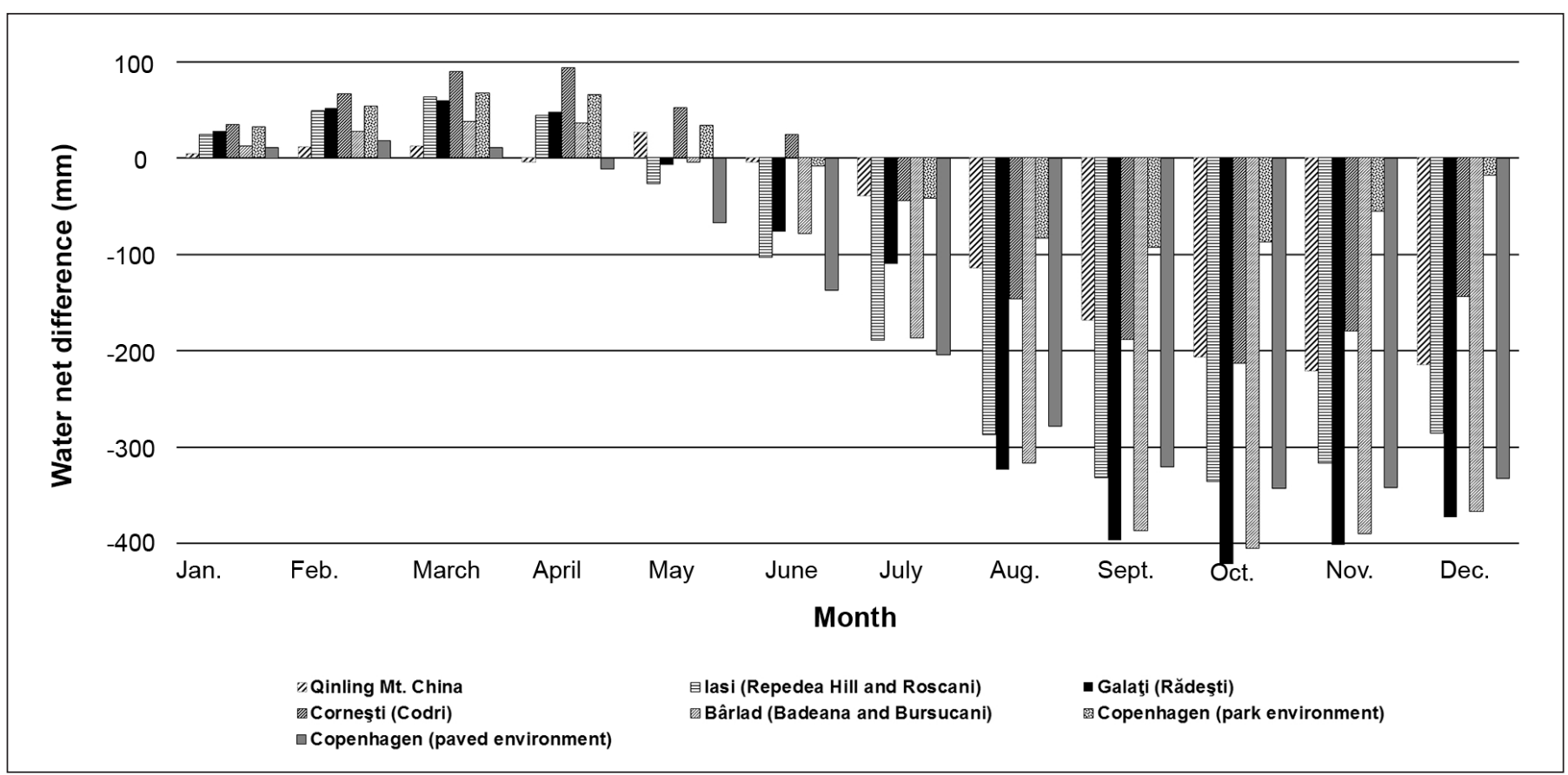

Figure 3. Calculated potential net differences in the study plots and at urban paved sites and park environments in Copenhagen, Denmark, illustrating the site match between the study plots and urban sites (after Sjöman et al. 2010 and Sjöman et al. 2012).

with warm and periodically dry summer climates, a more detailed investigation of the plant material should be conducted.

In evaluation of species growth and development, data on height, DBH, and age are collected. Drilling or coring for annual growth count allows the age of the trees to be established (Grissino-Mayer 2003). Growth data make it possible to calculate the development of a species on a particular site. Species showing relatively slow and/or underdeveloped growth in these types of habitats can be detected and the following process can instead focus on the species that develop more rapidly into rather large trees in this type of habitat. Statistical conclusions with greater accuracy can be secured by using a large number of individuals representing a wide range of ages in the growth data collection. The position of the individual tree in the stand is also documented, distinguishing canopy from understory. Trees in the canopy layer modify the wind, humidity, and temperature microclimate for species in the understory layer. Canopy species suffer from much higher transpiration due to high amount of wind and direct exposure to sunlight, and thereby warmer temperatures (Oliver and Larson 1996).

Data on growth and position of species within the forest stand, together with information on species occurrence in different habitats of the region, provide a qualitative approach to identify species that are generalists and those that are specialists (Rabinowitz 1981; Oliver and Larson 1996; Gurevitch et al. 2002). Species that exist in many types of habitats, yet in limited numbers, and show slow and/or underdeveloped growth on warm and periodically dry sites, while performing much better in cooler and moister sites, indicate an extensive plasticity (habitat generalists). Species that have a limited habitat preference for more or less warm and periodically dry habitats, but still develop into old and tall growing trees, are habitat specialists (Gurevitch et al. 2002). Species with their main position in the canopy layer are probably more tolerant to warmer temperatures and have much more effective transpira- tion compared with species in the understory (Oliver and Larson 1996). By assessing the habitat distribution, individual growth and position of species within the forest structure, comprehensive knowledge is gained on which species to evaluate further.

\section{Step 4: Collecting Seeds of Potential Trees}

It is important to consider the genetic diversity within the species in order to avoid genetic depletion, which may affect development and establishment in a new region. Mijnsbrugge at al. (2010) concluded that population differentiation is well documented for several species. It is important for climatic adaptation when selecting proper seed sources, as well as for site tolerance (Santamour et al. 1980; Xinguo and Zhiti 1998; Mijnsbrugge et al. 2010). For example, Sorbus torminalis (L.) Crantz. has a large natural distribution over central and eastern Europe and material originating from steppe forests in southeast Europe. The tree has a higher tolerance for warmer and drier site situations than trees from the British Isles (Demesure et al. 2000; Paganová 2007). Genotypes from southeast Europe are tentatively better suited to these warm and periodically dry conditions, while material from the British Isles is better suited to cool, moist park environments. It is also important that at least 50 individuals are included in the seed sample collection in order to achieve as large genetic variation as possible and thus optimal biological insurance against limited variation and low fitness (e.g., Hughes and Stachowicz 2004; Mijnsbrugge et al. 2010).

\section{CASE STUDIES}

In comparisons of potential water net differences between the case study areas in China and Romania/Moldavia with urban sites in the CNE-region (Figure 3), the study plots in the Qinling Mountains showed little difference between each other and 
the data are therefore combined. In contrast, the study sites in Romania and Moldavia exhibited large climatological and site-related differences and are hence presented separately. In order to detect site matching between the study sites and the CNE-region, the site-related data are compared with two different site situations in the inner-city environment of Copenhagen, Denmark: 1) urban paved sites; and 2) urban park environments. Copenhagen is used as an example to illustrate growing conditions in a large city in the northern CNE-region.

The mean annual temperature of Copenhagen is $8^{\circ} \mathrm{C}-12^{\circ} \mathrm{C}$ (an additional $1{ }^{\circ} \mathrm{C}-3^{\circ} \mathrm{C}$ when UHI is included) (US EPA 2009; DMI 2011). Mean annual precipitation in Copenhagen is $525 \mathrm{~mm}$ (DMI 2011). When calculating potential water stress (net water difference) for the sites in Copenhagen, park environments were assumed to have $10 \%$ water runoff and paved areas $70 \%$ water runoff(P902004).

\section{Case study 1: Qinling Mountains, China}

China is considered the most species-rich region of the world (Körner and Spehn 2002; Tang et al. 2006). The Qinling Mountain range is situated in the central, temperate part of the country and forms a botanic border between the southern and northern regions of China, consequently hosting a species-rich flora (Ying and Boufford 1998). Shaanxi province, where the Qinling Mountains are situated, is reported to have 1224 indigenous woody species (Kang, pers. comm. 2009), compared with only 166 in the Nordic countries (Mossberg and Stenberg 2003). The relatively northern location of the mountain range combined with its high altitudes means that plants are exposed to cold winters and warm summer months with periods of intense drought locally (Takhtajan 1986; Breckle 2002) - conditions thar are comparable to the climate in urban sites of the CNE-region. Field studies were carried out within three different areas in the north of the Qinling Mountain range, located between 1150 and 1590 meters a.s.l. (Sjöman et al. 2010). At the study site, the mean annual temperature in the area ranges from $9^{\circ} \mathrm{C}$ to $12^{\circ} \mathrm{C}$. The mean annual precipitation is $830 \mathrm{~mm}$ where $50 \%$ of the precipitation occurs predominantly from May to July, mainly as heavy rainstorms (Liu and Zhang 2003; Tang and Fang 2006).

The sites for the field studies were located based on climate data, literature, guiding by local botanists, and field inventories. In total, 20 study plots were inventoried, with a total area of $2,800 \mathrm{~m}^{2}$ and including a total number of 306 trees divided between 25 species.

\section{Evaluation of site conditions and tree growth}

The direct exposure to sunlight on the steep slopes creates low air humidity and rapid drying of the soil, which is comparable to the situation at many urban paved sites (Sieghardt et al. 2005). The low organic matter content (mean 3.6\%) and neutral $\mathrm{pH}$ (mean 6.7) are similar to values reported for urban sites (Craul 1999; Table 1). The soil texture was similar for all plots, with high to very high levels of silt (mean 53\%) and low levels of clay (mean 2.3\%; Table 1).

In calculation of potential water net difference, based on Thornthwaite (1948), the study plots experienced partial water stress in April and June, with more severe water stress in July and the remainder of the growing season (Figure 3). In comparison with urban sites in Copenhagen, the study plots experienced higher levels of water stress than park environments but less stress than paved environments. This discrepancy in water stress status is mainly due to higher precipitation rates in Qinling (Table 2). However, temperatures during the study period were $4.7^{\circ} \mathrm{C}$ higher at the site in China, leading to much higher evapotranspiration when compared with Copenhagen.

A large proportion of the 25 species in the study plots were growing mainly or exclusively on steep, south-facing slopes, while other species occurred both on south-facing slopes and in valleys and slopes with different orientation. The growth pattern of the species in the latter group was slow and/or underdeveloped, primarily occurring in the understory (Sjöman et al. 2010). In contrast, Ailanthus altissima, Carpinus turczaninowii, Celtis bungeana, Fraxinus chinensis, Koelreuteria paniculata, Morus mongolica, Ostrya japonica, Quercus aliena var. acuteserrata, $Q$. baronii, $Q$. wutaishanica, Sorbus folgneri, Syringa pekinensis, Ulmus glauescens, and U. pumila were mainly found on steeper parts of south-facing slopes. Here, the species had developed into tall, old trees and were present in the canopy as well as in the understory layer (Table 3). Among the species cited, six, A. altissima, $K$. paniculata, $Q$. aliena var. acuteserrata, Q. wutaishanica, S. folgneri, and S. pekinensis, had an annual mean height growth of $20 \mathrm{~cm}$ or more (Table 3 ).

\section{Case Study 2: Northeast Romania and Moldavia}

Northeast Romania and the Republic of Moldavia have a temperate continental climate, with hot summers, long, cold winters, and distinct seasons. Due to the higher summer temperatures and lower rainfall compared with Western Europe, large forest steppe systems have developed in this area (Breckle 2002). The field studies were carried out in six semi-natural forest reserves. Climate data for the field study areas (Table 2) were obtained from the nearby meteorological stations (Sjöman et al. 2012).

In Romania and Moldavia the microclimate had less influence on the study sites due to topographical differences being small. In total, 30 study plots where inventoried, with an allocated area of 1.2 ha, including 1159 trees representing 23 species (Sjöman et al. 2012).

\section{Evaluation of site conditions and tree growth}

The climate of the area, with cold winters and warm, dry summers, has clear similarities to inner-city environments in the CNE-region (Breckle 2002; Sieghardt et al. 2005). Based

Table 1. Selected properties of the soil in the study sites. Values shown are the mean of three different sampling depths (after Sjöman et al. 2010 and Sjöman et al. 2012).

\begin{tabular}{|c|c|c|c|c|}
\hline Area & Mean clay $(\%)$ & Mean silt (\%) & Mean humus (\%) & Mean $\mathrm{pH}$ \\
\hline Qinling Mt. (China) & 2.3 & 53.0 & 3.6 & 6.7 \\
\hline Codri (Moldavia) & 27.3 & 54.1 & 4.4 & 6.1 \\
\hline Rădeşti (Romania) & 16.5 & 35.8 & 4.0 & 5.4 \\
\hline Roşcani (Romania) & 33.0 & 58.1 & 2.7 & 5.0 \\
\hline Bădeana (Romania) & 17.8 & 28.7 & 2.4 & 5.9 \\
\hline Bursucani (Romania) & 16.4 & 33.8 & 1.8 & 4.8 \\
\hline
\end{tabular}

(C)2012 International Society of Arboriculture 
Table 2. Mean monthly temperature $\left({ }^{\circ} \mathrm{C}\right)$ and precipitation $(\mathrm{mm})$ at the study sites (after Sjöman et al. 2010 and Sjöman et al. 2012).

\begin{tabular}{|c|c|c|c|c|c|c|c|c|c|c|c|c|c|}
\hline & Jan & Feb & Mar & April & May & June & July & Aug & Sep & Oct & Nov & Dec & Annual mean \\
\hline \multicolumn{14}{|l|}{ Qinling Mt. (China) } \\
\hline Mean monthly temp. & 3.8 & 4.8 & 9.8 & 13.3 & 14.8 & 23.3 & 24.3 & 21.3 & 16.3 & 12.8 & 7.3 & 0 & $M=12.7$ \\
\hline Precipitation & 25 & 49.5 & 82.5 & 99 & 181.5 & 140.5 & 124 & 66 & 25 & 8 & 8 & 16.5 & $\mathrm{~S}=825.5$ \\
\hline \multicolumn{14}{|c|}{ Repedea Hill and Roşcani (Romania) } \\
\hline Mean monthly temp. & 0 & 0.4 & 3.6 & 11.2 & 16.6 & 20.8 & 22 & 20.9 & 15.7 & 9.9 & 4 & 0 & $M=10.4$ \\
\hline Precipitation & 27 & 28 & 29 & 36 & 34 & 64 & 74 & 70 & 56 & 48 & 31 & 35 & $S=532$ \\
\hline Mean monthly temp. & 0 & 0 & 4.1 & 10.6 & 16.5 & 20.3 & 22.6 & 22 & 17.6 & 11.5 & 5.2 & 0 & $\mathrm{M}=10.5$ \\
\hline Precipitation & 30.7 & 26.6 & 23.6 & 37.4 & 49.2 & 66.3 & 47.3 & 40.5 & 38.7 & 33.4 & 34.5 & 32.3 & $S=460.5$ \\
\hline \multicolumn{14}{|l|}{ Codri (Moldavia) } \\
\hline Mean monthly temp. & 0 & 0 & 1.9 & 9 & 15 & 18.1 & 20.6 & 20 & 15.5 & 9.6 & 3.1 & 0 & $\mathrm{M}=8.7$ \\
\hline Precipitation & 38.8 & 34.8 & 33.8 & 52 & 59.4 & 99.1 & 83.8 & 59.8 & 61.8 & 27.8 & 46 & 40.1 & $S=637.2$ \\
\hline \multicolumn{14}{|c|}{ Bădeana and Bursucani (Romania) } \\
\hline
\end{tabular}

Table 3. Tree species considered by habitat specialists and located in plots in the two case studies, numbers present, yearly mean increment in height $(\mathrm{m})$ and DBH $(\mathrm{cm})$. The structural position divides the trees into canopy trees/understory trees. The use-experiences of the species in the CNE-region is divided between species, which are (1) all more or less commonly used in urban environments of the region, and (2) those where prior experiences of their performance and plasticity is limited or nonexisting for the region (after Sjöman et al. 2010 and Sjöman et al. 2012).

\begin{tabular}{|c|c|c|c|c|c|}
\hline Species & $\begin{array}{l}\text { No. of } \\
\text { trees }\end{array}$ & $\begin{array}{l}\text { Yearly mean } \\
\text { increment in } \\
\text { height }(\mathrm{m})\end{array}$ & $\begin{array}{l}\text { Yearly mean } \\
\text { increment in } \\
\mathrm{DBH}(\mathrm{cm})\end{array}$ & $\begin{array}{l}\text { Structural } \\
\text { position }\end{array}$ & $\begin{array}{l}\text { Use-experiences } \\
\text { in the CNE-region }\end{array}$ \\
\hline Acer campestre $\mathrm{L}$. & 92 & 0.26 & 0.28 & $68 / 24$ & 1 \\
\hline Acer tataricum $\mathrm{L}$. & 92 & 0.18 & 0.22 & $3 / 89$ & 1 \\
\hline Ailanthus altissima (Mill.) Swingle. & 14 & 0.26 & 0.36 & $10 / 4$ & 1 \\
\hline Carpinus betulus L. & 95 & 0.29 & 0.30 & $38 / 57$ & 1 \\
\hline Carpinus orientalis Mill. & 112 & 0.19 & 0.22 & $29 / 83$ & 2 \\
\hline Carpinus turczaninowii Hauce. & 15 & 0.16 & 0.26 & $6 / 9$ & 2 \\
\hline Celtis bungeana Blume. & 12 & 0.16 & 0.21 & $10 / 2$ & 2 \\
\hline Cornus mas L. & 82 & 0.17 & 0.17 & $2 / 81$ & 1 \\
\hline Crataegus monogyna Jacq & 48 & 0.16 & 0.22 & $0 / 48$ & 1 \\
\hline Fraxinus chinensis Roxb. & 8 & 0.16 & 0.23 & $4 / 4$ & 2 \\
\hline Fraxinus excelsior L. & 32 & 0.31 & 0.38 & $25 / 7$ & 1 \\
\hline Koelreuteria paniculata Laxm. & 13 & 0.25 & 0.40 & $12 / 1$ & 1 \\
\hline Morus mongolica (Bur.) Schneid. & 6 & 0.16 & 0.30 & $5 / 1$ & 2 \\
\hline Ostrya japonica Sarg. & 5 & 0.19 & 0.32 & $4 / 1$ & 2 \\
\hline Quercus aliena var. acuteserrata Maxim. & 23 & 0.24 & 0.36 & $15 / 9$ & 2 \\
\hline Quercus dalechampii Ten. & 105 & 0.26 & 0.38 & $98 / 7$ & 2 \\
\hline Quercus frainetto Ten. & 95 & 0.26 & 0.36 & $86 / 9$ & 1 \\
\hline Quercus pubescens Wild. & 152 & 0.21 & 0.33 & $124 / 28$ & 2 \\
\hline Quercus robur $\mathrm{L}$. & 31 & 0.25 & 0.43 & $31 / 0$ & 1 \\
\hline Quercus wutaishanica Magr. & 14 & 0.25 & 0.35 & $14 / 0$ & 2 \\
\hline Sorbus folgneri (C.K. Schneid) Rehder. & 17 & 0.22 & 0.23 & $2 / 12$ & 2 \\
\hline Sorbus torminalis (L.) Crantz & 27 & 0.21 & 0.26 & $4 / 23$ & 1 \\
\hline Syringa pekinensis Rupr. & 6 & 0.21 & 0.30 & $2 / 4$ & 2 \\
\hline Tilia tomentosa Moench. & 165 & 0.36 & 0.46 & $121 / 44$ & 1 \\
\hline Ulmus glausescens Franch. & 34 & 0.17 & 0.22 & $23 / 11$ & 2 \\
\hline Ulmus pumila $\mathrm{L}$. & 25 & 0.12 & 0.20 & $8 / 17$ & 2 \\
\hline
\end{tabular}

on soil analysis, the sites could be divided into two separate groups (Table 1). Bădeana, Bursucani, and Rădești had comparable lower levels of clay and silt and therefore had lower water-holding capacity compared with Codri, Repedea Hill, and Roscani (Table 1). Furthermore, the humus content differed between the plots, with Codri and Rădești having mean values over $4 \%$, while the remaining sites had less than $2.7 \%$ (Table 1 ).
Calculations of potential water stress showed that the sites at Iași had an early negative net water balance in May, while Galați and Bârlad had a lower negative net water balance during the same period (Figure 3). This difference continued throughout June. At Iași and Bârlad, the negative net water balance in July increased much more rapidly, while the trend was less dramatic at Galaţi. However, in August, Galaţi experienced a significant al- 
teration, with a peak negative net water balance (Figure 3) due to its southerly location with a warmer summer climate and low levels of precipitation (Table 2). In early autumn Galaţi experienced the highest water deficit, followed by Bârlad and Iași (Figure $3)$. With its lowest net water balance in July onwards and with no abrupt changes, Corneşti deviated from the other study areas (Figure 3) due to higher precipitation $(637.2 \mathrm{~mm})$ and lower mean annual temperature $\left(8.7^{\circ} \mathrm{C}\right)$ (Table 2$)$. Codri differed from the other five study areas due to higher precipitation and lower mean annual temperature, whereas the other sites had rather similar water stress status over the season. Rădeşti had a somewhat more slowly developing negative net water balance early in the season compared with Bădeana, Bursucani, Repedea Hill, and Roşcani, but had a much more rapid negative trend in August. In the comparison between the study sites and urban environments in Copenhagen, Codri showed a closer match with park environments, while the other study sites showed a closer match with paved sites (Figure 3; Sjöman et al. 2012).

A total number of 1159 trees, representing 23 species, were found in 30 plots throughout the six different areas (Table 3 ). The following 13 species had 25 individuals or more occurring in the study plots: Acer campestre, A. tataricum, Carpinus betulus, $C$. orientalis, Cornus mas, Crataegus monogyna, Fraxinus excelsior, Quercus dalechampii, Q. frainetto, Q. pubescens, $Q$. robur, Sorbus torminalis, and Tilia tomentosa (Table 3). Of these, seven species, Acer campestre, Carpinus betulus, Fraxinus excelsior, Quercus dalechampii, $Q$. frainetto, $Q$. robur and Tilia tomento$s a$, had an annual mean height growth of $25 \mathrm{~cm}$ or more (Table 3 ). Four oak species, $Q$. dalechampii, $Q$. frainetto, $Q$. pubescens, and $Q$. robur, together with $F$. excelsior, were mainly present in the canopy layer, while A. tataricum, C. mas, C. monogyna, and $S$. torminalis were mainly present in the understory layer (Table 3). The remaining species were present in high numbers of individuals in both structural layers of the stands (Table 3).

\section{DISCUSSION}

As has been suggested by a number of authors, investigating the ecological background and performance of species growing in habitats that naturally experience drought during the growing season and winter temperatures similar to those of inner-city environments provides a sound and reliable selection method (Flint 1985; Ware 1994; Ducatillion and Dubois 1997; Broadmeadow et al. 2005; Sæbø et al. 2005; Roloff et al. 2009). The dendroecological studies described here in the Qinling Mountains of China and the steppe forests of Romania and the Republic of Moldavia present an approach for identifying alternative trees for future urban use in the CNE-region. As noted by Roloff et al. (2009), dendroecological descriptions are seldom or never available for most species. By starting the selection process with dendroecological studies in natural habitats with similar climate and site situations as inner-city environments, first-hand information can be gained on species growth and performance in these climates and habitats.

This first stage in the selection process can thus screen out species showing slow and/or underdeveloped growth in habitats similar to urban inner-city environments. This allows the focus to be directed towards the species in these natural sites that develop rapidly into large trees. This first stage consequently identifies genotypes of the species that ought to be included in the following steps at an early phase of the procedure. In the Qinling Mountains of China and the steppe forests of Romania and Moldavia, a total of 27 tree species (genotypes) were identified as specialists for warm and periodically dry habitats (Rabinowitz 1981; Gurevitch et al. 2002).

The trees at the study sites all experienced drier conditions than those in park environments in Copenhagen. In the match between the study sites and paved environments in the cities, all the sites in Romania and Moldavia except Codri showed a comparable water net difference. Hence, the 27 species identified as developing rather rapidly into large trees at the field sites are all potential trees for tough sites experiencing drier conditions than traditional park environments.

The 27 tree species can be divided into two groups depending on their use background in the CNE-region (Table 3). Acer campestre, A. tataricum, A. altissima, Carpinus betulus, Cornus mas, Crataegus monogyna, Fraxinus excelsior, Koelreuteria paniculata, Quercus frainetto, $Q$. robur, Sorbus torminalis, and Tilia tomentosa are all more or less commonly used in urban environments of the region, mainly as park trees (e.g., Bengtsson 1998; Forrest 2006), and are also available from tree nurseries in Europe (e.g., Lorenz von Ehren 2004; Lappen 2007; Bruns 2009). For Carpinus orientalis, C. turczaninowii, Celtis bungeana, Fraxinus chinensis, Morus mongolica, Ostrya japonica, Quercus aliena var. acuteserrata, $Q$. baronii, $Q$. dalechampii, $Q$. pubescens, Q. wutaishanica, Sorbus folgneri, Ostrya pekinensis, Ulmus glaucescens, and U. pumila prior experience of the performance and plasticity is limited or nonexistent for the CNE-region (Nitzelius 1958; Bengtsson 1998).

In the selection model presented here, two groups of species are discernible. Group 1 comprises species already in use in the urban environment where prior knowledge and experience of pest resistance, propagation issues, and wood stability already exists. However, it is essential to use the appropriate genotypes in order to select specimens with the properties identified at study sites (Jones et al. 2001; Mijnsbrugge et al. 2010). However, even if it is necessary to re-evaluate these wellknown species (genotypes), collected from the study sites, their introduction will be a rather quick procedure due to the prior knowlege of the same species already used in the urban setting.

Group 2 includes species for which prior experience of performance in urban environments is limited or non-existent in the CNE-region. Evaluation of these 15 tree species identified in the case studies in China, Romania, and Moldavia would be a much more time-consuming procedure before any full-scale trials could be performed in urban settings. The offspring would have to be planted in controlled field trials, for further evaluation, in order to obtain knowledge and experience concerning hardiness, growth and development, wood stability, pest resistance, invasiveness risks, and propagation issues. Species must then be tested in full-scale trials in urban environments of the CNE-region.

The obvious advantage of studying habitats and evaluating well-known species is that the subsequent selection process is much shorter and this tree stock can be introduced immediately once proper genotypes are available and tested. This process also considers trees that are currently used exclusively in park environments but could possibly be transferred into street environments. However, it is equally important to have longterm approaches where many new and untested species and genera can be identified in order to increase the diversity of 
the urban tree population. Subsequent selection and searches for complementary tree species do not need to exclusively address new and untested species. Further information on species already used in the urban landscape, taken from their natural habitat, will increase the current body of knowledge and illustrate new use-functions for these well-known species.

The approaches in evaluating species which are more or less commonly used in urban environments of the CNE-region and those where prior experiences of their performance and plasticity is limited or non-existing for the region were taken into consideration when selecting the different case study areas. The mountains of China host an impressive richness of species (Ying and Boufford 1998) and the potential to detect a large number of species and genera never used in cultivation before is large. Of 14 tree species identified in China, 12 have never been grown or grown to a very limited extent in the CNE-region. The Romania and Moldavia cases were chosen on the basis that many well-known species occur in the region but knowledge about their site plasticity is sparse. Only three of 13 species were associated with a lack of prior knowledge on their performance (Bean 1980). Of the 27 tree species identified, only Acer campestre, Caprinus betulus, Crataegus monogyna, and Fraxinus excelsior are considered much used or used to some extent in northern Europe (Sæb $\varnothing$ et al. 2005). Thus, the 23 tree species identified in those field studies can be potential supplements for diversification of the urban tree population in the CNE-region. Since the two case study areas differ from each other in terms of the number of individuals present of potential species, the analysis of the findings also differed between the two case studies. The Qinling Mountains host a large diversity of tree species (Ying and Boufford 1998) and few of each species are present in the forest stands, so the amount of rare species scattered in the forest systems is large. The results from the China study were therefore interpreted using a more qualitative approach (Sjöman et al. 2010). A quantitative approach was possible in the case study in Romania and Moldavia, since the forests there included more species that were present at the sites in large numbers and rare species were few (Sjöman et al. 2012).

Distinguishing between species with their main position in the canopy layer and those in the understorey layer makes it possible to pinpoint a particular use potential. Trees in the canopy layer modify the wind, humidity and temperature microclimate for species in the understorey layer. Canopy species, on the other hand, suffer from much higher transpiration due to their exposure to wind and warmer temperatures (Oliver and Larson 1996). In the two case studies tree species with their main position in the canopy layer were A. altissima, Celtis bungeana, Fraxinus excelsior, Koelreuteria paniculata, Morus mongolica, Ostrya japonica, Quercus aliena var. acuteserrata, $Q$. dalechampii, $Q$. frainetto, $Q$. pubescens, $Q$. robur, and $Q$. wutaishanica (Sjöman et al. 2010; Sjöman et al. 2012). Thus, these species experienced a more stressful environment, with much higher evapotranspiration rates compared with the species in the following structure. This distribution indicates that species only or mainly existing in the canopy layer in mature forest stands have difficulties in germinating and developing successfully under shading tree crowns (Oliver and Larson 1996; Gurevitch et al. 2002). These species have great use potential in warm and sun-exposed sites, such as town squares and courtyards. Acer campestre, Carpinus betulus, Caprinus orientalis, C. turczaninowii, Fraxinus chinensis, Quercus baronii, Syringa pekinensis, Tilia tomentosa, and
Ulmus glaucescens had individuals in both the canopy layer and the understorey layer (Table 3). Species capable of developing successfully in both the canopy and understorey layer may be useful in e.g. street plantations, where the light and temperature conditions can differ greatly between the two sides of the street (Sieghardt et al. 2005). Moreover, Acer tataricum, Cornus mas, Crataegus monogyna, Sorbus folgneri, Sorbus torminalis, and Ulmus pumila were all found growing primarily in the understorey layer and can be useful either in warm courtyards and squares that are shaded for most of the day, or as understory vegetation underneath existing trees, as with paved sites (Sjöman et al. 2010; Sjöman et al. 2012). However, these latter species can probably tolerate sunnier and hence drier and warmer conditions, since they all exist in forest edge zones, but inside the forest stands they cannot compete with other much taller species and have therefore developed a tolerance for more shaded conditions.

This study focused on trees that in their natural sites are exposed to warm and dry growth conditions, since water stress is argued to be the main constraint for tree growth and health in urban environments (e.g., Craul 1999; Hoff 2001; Sieghardt et al. 2005; Nielsen et al. 2007; Roloff et al. 2009). It is important to bear in mind that this process with dendroecological habitat studies in order to identify potential urban trees is just the first step in the selection process. Further research is necessary in order to evaluate the species tolerance towards warm and periodically dry growth conditions in another geographical area and towards other stressors, such as de-icing substrates or air pollution. Nevertheless, this approach constitutes a faster and more effective route, since subsequent selection work can focus on species with high potential for the purpose instead of testing species randomly. Dendroecological studies, as presented in this paper, contribute to an ecological understanding that provides for a much wider knowledge base in the selection process, thus helping to evaluate the reaction, tolerance, and performance of different tree species to different stressors. Furthermore, dendroecological studies provide valuable guidance regarding the use potential of species, which can be of importance in their subsequent evaluation in full-scale plantations in urban environments.

It is also important to note the invasiveness risks of species included in these types of studies. Relevant research on these aspects in parallel with ongoing selection work can help prevent the introduction of invasive species and genotypes. Dendroecological studies in natural habitats, as presented in this text, can also provide some guidance on this issue. By identifying the ecological strategies, including disposal and reproductive traits of species and genotypes in their natural settings, it is possible to determine their potential to escape from cultivation and become an aggressive competitor in natural habitats in another region (Pyšek and Richardson 2007; Pyšek et al. 2009).

\section{LITERATURE CITED}

Barry, R.G. 2008. Mountain Weather and Climate. Cambridge University Press, Cambridge, UK. 506 pp.

Bean, W.J. 1980. Trees and Shrubs Hardy in the British Isles. 4th volume, Eight Edition Revised. John Murray Ltd, London, England.

Bengtsson, R. 1998. Stadsträd från A-Z (Street Trees from A-Z). Stad \& Land nr. 154:1998, SLU, Alnarp, Sweden. 168 pp. (In Swedish)

Breckle, S.W. 2002. Walter's Vegetation of the World. 4th edition. Springer. 527 pp. 
Broadmeadow, M.S.J., R. Ray, and C.J.A. Samuel. 2005. Climate change and the future for broadleaved tree species in britain. Forestry 78(2):145-161.

Bruns. 2009. Bruns Pflanzen, Bad Zwischenahn, Germany. 924 pp.

Buránek, V., M. Benedíkova, and J. Kyselákova. 2011. Evaluation of twenty-years-old pedunculate and sessile oak provenance trials. Journal of Forest Science 57(4):153-169.

Burga, C.A., F. Klötzli, and G. Grabherr. 2005. Gebirge der Erde: Landschaft, Klim und Pflanzenwelt (Mountains of the world: landscape, climate and plant world). Ulmer, Stuttgart, Germany. 504 pp. (In German)

Bühler, O., P. Kristoffersen, and S.U. Larsen. 2007. Growth of street trees in Copenhagen with emphasis on the effect of different establishment concepts. Arboriculture \& Urban Forestry 33:330-337.

Craul, P.J. 1999. Urban Soil - Applications and Practices. John Wiley \& Sons, Canada. 366 pp.

Demesure, B., B. Le Guerroué, G. Lucchi, D. Prat, and R.J. Petit. 2000. Genetic variability of a scattered temperate forest tree: Sorbus torminalis L. (Crantz). Annuals of Forest Science 57:63-71.

DMI. 2011. Danish Meteorological Institute. Accessed June 15, 2011. $<$ www.dmi.dk>

Ducatillion, C., and E. Dubois. 1997. Diversification des plantes ornimentales méditerranéennes: estimation des besoins qualitatifs des villes en arbres et arbustes (Diversification of ornamental mediterranean plants: assessment of the qualitative needs of cities concerning trees and shrubs), In: INRA (Ed.). La plante dans la ville, Angers, pp. 139-149. (In French)

Duhme, F., and S. Pauleit. 2000. The dendrofloristic richness of SE-Europe, a phenomenal treasure for urban plantings. Mitteilungen aus der Biologischen Bundesanstalt für Land- und Forstwirtschaft BerlinDahlem 370:23-39.

EEA (European Environment Agency). 2008. Impacts of Europe's changing climate - 2008 indicator-based assessment. EEA Report No 4/2008. Office for Official Publications of the European Communities, Luxembourg.

Ellenberg, H. 1988. Vegetation Ecology of Central Europe. 4th edition, Cambridge University Press, Cambridge. 731 pp.

FAO. 2006. Guidelines for Soil Description. Food and Agriculture Organization of the United Nation, 4th edition, Rome. $97 \mathrm{pp}$.

Flint, H.L. 1985. Plants showing tolerance of urban stress. Journal of Environmental Horticulture 3(2):85-89.

Forrest, M. 2006. Landscape trees and shrubs - selection, use and management. Athenaeum Press, Gateshead. 179 pp.

Foster, R.S., and J. Blaine. 1977. Urban tree survival: Trees in the sidewalk. Journal of Arboriculture 4(1):14-17.

Gilbertson, P., and A.D. Bradshaw. 1990. The Survival of Newly Planted Trees in Inner Cities. Arboricultural Journal 14:287-309.

Gill, S.E., J.F. Handley, A.R. Ennos, and S. Pauleit. 2007. Adapting cities for climate change: The role of the green infrastructure. Built Environment 33(1):115-133.

Gómez-Muñoz, V.M., M.A. Porta-Gándara, J.L. Fernández. 2010. Effect of Tree Shades in Urban Planning in Hot-arid Climatic Regions. Landscape and Urban Planning 94(3-4):149-157.

Grabosky, J., and N. Bassuk. 1996. Testing of structural urban tree soil materials for use under pavement to increase street tree rooting volumes. Journal of Arboriculture 22(6):255-263.

Grissino-Mayer, H.D. 2003. A Manual and tutorial for the proper use of an increment borer. Tree-Ring Research 59(2):63-79.
Gurevitch, J., S.M. Scheiner, G.A. Fox. 2002. The Ecology of Plants. Sinauer Associates, Inc. Publisher, Sunderland, Massachusetts, U.S. $523 \mathrm{pp}$.

Hoff, H. 2001. Climate change and water availability. In: J.L. Lozán, H. Grassel, P. Hupfer (Eds.). Climate of the 21st century: Changes and risks. pp. 315-321. Wissenschaftliche Auswertungen, Hamburg, Germany.

Hughes, A.R., and J.J. Stachowicz. 2004. Genetic diversity enhances the resistance of a seagrass ecosystem to disturbance, Proceedings of the National Academy of Sciences 101:8998-9002.

Jones, A.T., M.J. Hayes, N. Sackville Hamilton. 2001. The Effect of provenance on the performance of Crataegus monogyna in hedges. Journal of Applied Ecology 38:952-962.

Kollmann, J., and A. Fischer. 2003. Vegetation as indicator for habitat quality. Basic and Applied Ecology 4(6):489-491.

Kristoffersen, P. 1999. Growing trees in road foundation materials. Arboricultural Journal 23:57-76.

Körner, C., and E.M. Spehn. 2002. Mountain biodiversity: A global assessment. New York, New York: The Parthenon Publishing Group. $657 \mathrm{pp}$.

Lappen. 2007. Lappen Nursery. Nettetal-Kaldenkirchen, Holland. pp. 679.

Liu, S. F., and J. Zhang. 2003. Biodiversity research and conservation in Fu Ping nature reserve. Shaanxi Technology Publishing House. 662 pp. (In Chinese)

Lorens von Ehren. 2004. Lorenz von Ehren Nursery. Hamburg, Germany. pp. 1024.

Lu, P., and P. Charrette. 2008. Genetic parameter estimates for growth traits of black spruce in northwestern Ontario. Canadian Journal of Forest Research 38:2994-3001.

Mijnsbrugge, K.V., A. Bischoff, and B. Smith. 2010. A Question of Origin: Where and How to Collect Seed for Ecological Restoration. Basic and Applied Ecology 11:300-311.

Morgenroth, J., and R. Visser. 2011. Aboveground growth response of Platanus orientalis to porous pavements. Arboriculture \& Urban Forestry $37(1): 1-5$.

Mossberg, B., and L. Stenberg. 2003. Nya Nordiska Floran (The New Nordic Flora). Wahlström and Widstrand. 928 pp. (In Swedish)

Nielsen, C.N., O. Bühler, and P. Kristoffersen. 2007. Soil water dynamics and growth of street and park trees. Arboriculture \& Urban Forestry 33(4):231-245.

Nitzelius, T. 1958. Boken om träd (The Book About Trees). Saxon \& Lindströms förlag, Stockholm. 469 pp. (In Swedish)

Nowak, D.J. 2002. The effects of urban forests on the physical environment. In: T.B. Randrup, C.C. Konijnendijk, T. Christophersen, and K. Nilsson (Eds.). COST action E12 Urban Forests and Urban Trees. Proceedings No. 1. Office for Official Publications of the European Communities, Luxembourg. pp. 22-42.

Nowak, D.J., J.R. McBride, and R.A. Beatty. 1990. Newly Planted Street Tree Growth and Mortality. Journal of Arboriculture 16(5):124-129.

Oliver, C.D., and B.C. Larson. 1996. Forest Stand Dynamics. John Wiley \& Sons. 520 pp.

P90. 2004. Publication P90 - Dimension public sewer pipes. Svenskt Vatten AB. Ljungföretagen. (In Swedish)

Paganová, V. 2007. Ecology and distribution of Sorbus torminalis (L.) Crantz. Horticulture Science 34(4):38-151. (In Slovakia)

Pauleit, S., N. Jones, G. Garcis-Martin, J.L. Garcia-Valdecantos, L.M. Riviere, L. Vidal-Beaudet, M. Bodson, and T.B. Randrup. 2002. Tree Establishment Practise in Towns and Cities - Results from a European Survey. Urban Forestry \& Urban Greening 1(2):83-96. 
Pedersen, L.B., T.B. Randrup, and M. Ingerslev. 2000. Effects of road distance and protective measures in deicing $\mathrm{NaCl}$ deposition and soil solution chemistry in planted medium Strips. Journal of Arboriculture 26(5):238-245.

Perry, D.A. 1998. The Scientific Basis of Forestry. Annual Review of Ecology and Systematics 29:435-466.

Pyšek, P., D.M. Richardson. 2007. Traits Associated with Invasiveness in Alien Plants: Where do we stand? In: W. Nentwig (Ed.). Biological Invasions, Ecological Studies 193, Springer-Verlag, Berlin \& Heidelberg. pp. 97-126.

Pyšek, P., Krivánek, M., Jarošík, V., 2009. Planting intensity, residence time, and species traits determine invasion success of alien species. Ecology 90(10):2734-2744.

Påhlsson, L. 1998. Vegetation types in the Nordic countries. (Vegetationstyper i Norden) TemaNord 1998:510, Nordiska Ministerrådet, pp. 706. (In Swedish)

Rabinowitz, D. 1981. Seven forms of rarity. In: H. Synge (Ed.). The Biological Aspects of Rare Plant Conservation. pp. 205-217. John Wiley, Chichester, UK.

Roberts, J., N. Jackson, and M. Smith. 2006. Tree Roots in the Built Environment. Department for Comunities and Local Government, Norwich, England. 486 pp.

Roloff, A., S. Korn, and S. Gillner. 2009. The climate-species-matrix to select tree species for urban habitats considering climate change. Urban Forestry \& Urban Greening 8:295-308.

Sæbø A, B. Zelimir, C. Ducatillion, A. Hatzistathis, T. Lagerström, J. Supuka, J.L. Garcis-Valdecantos, F. Rego, and J. Slycken. 2005. The selection of plant materials for street trees, park trees and urban woodlands In: C.C. Konijnendijk, K. Nilsson, T.B. Randrup, and J. Schipperijn (Eds.). Urban Forests and Trees. pp. 257-280. Springer.

Santamour, F.S. 1990. Trees for urban planting: Diversity, uniformity and common sense. Proceedings of the 7th Conference of the Metropolitan Tree Improvement Alliance 7:57-65.

Santamour, F.S., P.W. Garret, and D.B. Paterson. 1980. Oak provenance research: The michaux quercetum after 25 years. Journal of Arboriculture 6(6):156-159.

Shigo, A.L. 1991. Modern Arboriculture. Shigo and Trees Associates, Durham, USA.

Sieghardt, M., E. Mursch-Radlgruber, E. Paoletti, E. Couenberg, A. Dimitrakopoulus, F. Rego, A. Hatzistatthis, and T.B. Randrup. 2005. The abiotic urban environment: Impact of urban growing conditions on urban vegetation. In: C.C. Konijnendijk, K. Nilsson, T.B. Randrup, and J. Schipperijn (Eds.). Urban Forests and Trees. Springer. 281-323 pp.

Sjöman, H., A.B, Nielsen, S. Pauleit, and M. Olsson. 2010. Habitat studies identifying potential trees for urban paved environments: A case study from Qinling Mt., China. Arboriculture \& Urban Forestry 36(6):261-271.

Sjöman, H., A.B. Nielsen, and A. Oprea. 2012. Trees for Urban Environments in Northern Parts of Central Europe - A Dendroecological Study in North-east Romania and Republic of Moldavia. Urban Ecosystem 15(1):267-281.
Sjöman, H., and G. Richnau. 2009. North-east Romania as a future source of trees for urban paved environments in north-west Europe. Journal of Plant Development 16:37-46.

Takhtajan, A. 1986. Floristic Atlas of the World. University of California Press. $522 \mathrm{pp}$

Tang Z., Z. Wang, C. Zheng, and J. Fang. 2006. Biodiversity in China's mountains. Frontiers in Ecology and the Environment 4(7):347-352.

Tang, Z., and J. Fang. 2006. Temperature variation along the northern and southern slopes of Mt. Taibai, China. Agricultural and Forest Meteorology 139:200-207.

Thornthwaite, C.W. 1948. An approach toward rational classification on climate. Geographical Review 38(1):55-94.

Trowbridge, P., and N. Bassuk. 2004. Trees in the Urban Landscape, Site Assessment, Design and Installation. John Wiley \& Sons, Inc. Hoboken, New Jersey, U.S. 207 pp.

Tyrväinen, L., L. Mäkinen, and J. Schipperijn. 2005. Tools for mapping social values for urban woodlands and of other green spaces. Landscape and Urban Planning 79(1):5-19.

US EPA. 2009. U.S. Environmental Protection Agency. Accessed July 2, 2011. <www.epa.gov/heatislands/>

Ware, G.H. 1994. Ecological bases for selecting urban trees. Journal of Arboriculture 20(2):98-103.

Xinguo, L., and Z. Zhiti. 1998. Selection of better combination of genotypes and sites of forest trees. Journal of Beijing Forestry University. 20(3):15-18.

Ying, T-S., and D.E. Boufford. 1998. Phytogeography of the Qinling Mountains and a comparison with the flora and vegetation of Japan. In: D.E. Boufford and H. Ohba. (Eds.) Sino-Japanese flora it's characteristics and diversification. The University Museum, The University of Tokyo, Bulletin No. 37.

\section{Henrik Sjöman (corresponding author)}

Landscape management, design and construction

PO Box 66

Alnarp, SE-23053 Sweden

henrik.sjoman@ltj.slu.se

\section{Allan Gunnarsson}

Landscape management, design and construction

Alnarp, Sweden

Stephan Pauleit

Strategic Landscape Planning and Management

Munich, Germany

\section{Roland Bothmer}

Plant Breeding and Biotechnology

Alnarp Sweden 
Résumé. Une diversité élevée en espèces et en genres ainsi qu'une grande capacité d'adaptation sont deux facteurs importants afin de tenter d'obtenir une population d'arbres urbains soutenue et en santé. Cet article présente et discute d'une procédure de sélection pour l'identification d'arbres adaptés aux environnements urbains. La procédure est basée sur les études dendrochronologiques d'arbres dans les habitats naturels avec des conditions de site et de climat similaires à celles des environnements urbains. En étudiant les arbres au sein de ces habitats, des informations de première main peuvent être obtenues sur la croissance et la performance pour une grande variété d'espèces et de génotypes. Deux études sur le terrain ont été menées, une dans le Centre de la Chine et une autre dans le Nord-est de la Roumanie et la République voisine de Moldavie avec pour objectif d'identifier les espèces d'arbres et les génotypes adaptés à l'intérieur des environnements urbains des parties septentrionales de l'Europe Centrale et des parties voisines plus tempérées du Nord de l'Europe. Au total, 27 espèces d'arbres ont été identifiées comme «spécialistes » des habitats périodiquement chauds et secs. Parmi ces espèces d'arbres, seulement quatre sont couramment employées ou encore sont employées à une assez large échelle dans le Nord de l'Europe, ce qui signifie que les 23 autres espèces identifiées dans ces études de cas pourraient devenir des alternatives potentielles pour une diversification des populations d'arbres urbains.

Zusammenfassung. Die hohe Vielfalt von Arten und Gattungen und deren Standortadaption mit zwei wichtige Faktoren im Erhalt einer gesunden und nachhaltigen urbanen Baumpopulation. Diese Studie präsentiert und diskutiert eine Auswahlprozedur für die Identifikation von Bäumen, die an innerstädtische Bedingungen adaptiert sind. Diese Prozedur basiert auf dendro-ökologischen Studien an Bäumen in ihren natürlichen Habitat, mit Gemeinsamkeiten in Klima und Standortbedingungen eines innerstädtischen Umfelds. Durch das Studium von Bäumen in solchen Habitaten können aus erster Hand Informationen zum Wachstum und der Performance einer weiten Spanne von Arten und Genotypen gewon- nen werden. Zwei Feldstudien durch durchgeführt, eine in Zentralchina und eine andere in Nordwestrumänien und der angrenzenden Republik Moldawien mit der Zielsetzung, an innerstädtische Bedingungen adaptierte Baumarten und Genotypen in den nördlichen Teilen von Zentraleuropa und den angrenzenden milderen Gegenden von Nordeuropa zu identifizieren. Insgesamt wurden 27 Baumarten als Spezialisten für warme und periodisch trockene Habitate identifiziert. Von diesen Baumarten werden gegenwärtig nur vier gelegentlich oder in gewissem Ausmaß in Nordeuropa genutzt, was bedeutet, dass die 23 identifizierten anderen Baumarten aus dieser Studie ein Potential für die Diversifikation urbaner Baumpopulationen besitzen.

Resumen. La alta diversidad de géneros y especies y la adaptación al sitio son dos factores importantes en la consecución de una población de árboles urbanos sanos y sostenibles. Este documento presenta y explica un procedimiento de selección para la identificación de árboles adaptados a ambientes de interior en la ciudad. El procedimiento se basa en estudios dendroecológicos de árboles en hábitats naturales, con similitudes en condiciones de clima y sitio como entornos de interior de la ciudad. Mediante el estudio de árboles en estos hábitats puede obtenerse información de primera mano sobre el crecimiento y el rendimiento de una amplia gama de especies y genotipos. Se realizaron dos estudios de campo, uno en China central y otro en el noreste de Rumania y la República adyacente de Moldavia, con el objetivo de identificar especies y genotipos adaptados a entornos de interior de la ciudad en la parte norte de Europa central y las partes adyacentes del norte de Europa. En total, se identificaron 27 especies de árboles como especialistas para un hábitat periódicamente seco y cálido. De estas especies de árboles, solo cuatro actualmente son utilizados con frecuencia o utilizados en cierta medida en el norte de Europa, lo que significa que otras 23 especies arbóreas identificadas en los estudios de casos pueden ser posibles suplementos para la diversificación de la poblaciones de árboles urbanos. 